\title{
PEMURNIAN AJARAN ISLAM KH FATHUL MUIN DG MAGGADING
}

\author{
Syandri \\ Salahuddin \\ M. Darwis Muhdina
}

\begin{abstract}
Abstrak: Tulisan ini membahas tentang pemurnian ajaran Islam dengan melakukan studi terhadap pemikiran KH Fathul Muin Dg Maggading. Penelitian ini adalah penelitian lapangan (field Research) yang bersifat kualitatif. Penelitian lapangan ini berhadapan dengan keluarga, murid langsung, dan para pemuda Muhammadiyah yang senantiasa bersama KH Fathul Muin Dg Maggading semasa hidup. Pendekatan yang digunakan adalah pendekatan historis, sosiologis dan filosofis. Sumber data primer dalam penelitian ini adalah buku hasil karya KH Fathul Muin Dg Maggading, Diktat pelajaran Keimanan 1 dan 2, Diktat Pelajaran Tafsir 1, Gerak Langkah Muhammadiyah Terlibat Dalam Kekaburan, melakukan observasi di kalangan keluarga dan para murid $\mathrm{KH}$ Fathul Muin Dg Maggading juga dengan merujuk pada agenda harian 1970 dan 1971. Sedangkan sumber sekunder adalah buku-buku yang menyangkut biografi ringkas KH Fathul Muin Dg Maggading, diantaranya: Matahari Pembaharuan di Serambi Madinah Menelusuri tepak sejarah Muhammadiyah Kota Makassar, Menepak Jejak Menata Langkah Sejarah Gerakan Dan Biografi Ketua-Ketua Muhamddiyah Sulawesi Selatan, dan terkhusus buku yang ditulis pada tahun 1966 berjudul Beginilah Muhammadijah Langkah dan Dharma Bakti Muhammadijah Tjab. Makassar. Data dikumpulkan melalui metode wawancara, observasi dan dokumentasi. Instrumen penelitian yang pada penelitian ini adalah dengan wawancara, wawancara mendalam, observasi, studi pustaka, dan data lokasi penelitian. Analisa data yang digunakan dalam penelitian ini adalah analisa data deduktif yang bertitik tolak dari pengetahuan umum tentang pemurnian ajaran Islam, kemudian mengambil kesimpulan yang bersifat khusus, setelah melakukan kajian mendalam terhadap pemikiran KH Fathul Muin Dg Maggading. Pekerjaan analisis data dalam hal mengatur, mengurutkan, mengelompokkan, memberi kode, dan mengkategorisasikan data yang terkumpul, baik dari catatan lapangan, gambar, foto atau dokumen berupa laporan.
\end{abstract}

Hasil penelitian di atas menunjukkan bahwa KH Fathul Muin Dg Maggading mendefenisikan kata tajdīd sebagai pemurnian, banyak hal yang mendorongnya untuk melakukan pemurnian, diantaranya masalah pudarnya pemahaman ummat Islam akan fungsi utama dari al-Quran dan al-Sunnah. Selain itu, kondisi sosial seperti kondisi ummat Islam yang dalam masa transisi atau peralihan kebudayaan, dimana ilmu-ilmu Barat sudah menjadi penentu ukuran kebenaran dalam kehidupan, demikian juga dengan politik, dimana Masyumi dibubarkan dan para pemimpin revolusioner disudutkan. Menurutnya hanya ada satu jalan untuk merealisasikan pemurnian ini yaitu kembali kepada al-Quran dan al-Sunnah. Ia membagi pemurnian kedalam tiga bagian yaitu 
pemurnian dalam bidang aqidah yaitu menjadikan al- Quran dan al-Sunnah sebagai satu-satunya landasan dalam kehidupan, ibadah yaitu tunduk dan patuh terhadap peraturan-peraturan yang telah disyariatkan dan muamalah yaitu menjadikan Islam sebagai jalan hidup (way of life) dimana ketiga bentuk pemurnian ini terinspirasi dari surah al-Fatihah.

\section{Keywords: Pemurnian Ajaran Islam; KH Fathul Muin Dg Maggading}

\section{PENDAHULUAN}

Gerakan pemurnian ajaran Islam KH Fathul Muin Dg Maggading merupakan salah satu gerakan yang sangat terkenal diera tahun 1980-an di sekitar Makassar, ia terkenal merupakan ulama yang sangat keras menyuarakan tentang pemurnian Islam. Gerakan pemurnian Islam merupakan fenomena penting dalam perkembangan pemikiran dan gerakan Islam. Ia seringkali muncul, tampaknya secara periodik, dalam situasi mana banyak terjadi penyimpangan baik dalam moral, pemahaman maupun pengalaman agama. Penyimpangan itu dipandang oleh para penganjur purifikasi (pemurnian) sebagai kemerosotan agama dan masyarakat Islam, dan mereka menyatakan bahwa agar agama itu mencapai kejayaan, agama itu sendiri harus dibersihkan dari segala penyimpangan, pengaburan, dan pengotoran yang berjangkit di kalangan umat Islam. Pemurnian dalam Islam akan terus menerus ada pada setiap zaman, sebagaimana disampaikan oleh Nabi saw dalam hadisnya bahwasanya pada setiap penghujung seratus tahun, Allah swt mengutus untuk umat ini orang yang akan memperbaharui agama mereka. ${ }^{1}$ Hadis ini sangat jelas menunjukkan adanya orang-orang yang senantiasa melakukan perbaikan di tengah-tengah umat.

Di Indonesia, pemurnian ajaran Islam silih berganti disuarakan dari generasi ke generasi, tidak terkecuali Makassar. Dari beberapa ulama yang melakukan purifikasi (pemurnian) di Sulawesi Selatan yang sangat terkenal adalah KH Fathul Muin Dg Maggading, akan tetapi sangat disayangkan kematiannya seakan menguburkan segala sumbangsinya dalam bidang ini. Ia merupakan sosok cikal bakal munculnya gerakangerakan Islam puritan di kawasan Indonesia Timur yang di mulai dari Makassar.

Ini juga memberikan gambaran bahwa perjalanan Islam di Sulawesi Selatan tidak pernah kering dari peran para ulama dan da'i. Sejak awal kali masuk di Sulawesi Selatan, ulama yang dalam bahasa Arab berasal dari akar kata īlim, berarti sebuah tanda atau kekhususan sesuatu. ${ }^{2}$ Adapun dalam kamus bahasa besar Indonesia diartikan sebagai orang yang ahli dalam bidang agama. ${ }^{3}$ Para ulama memiliki peran yang signifikan di dalam kehidupan sosial kemasyarakatan Indonesia. Mereka dipandang memerankan kepemimpinan regional yang efektif, ahli (memiliki kemampuan) dalam menghubungkan Islam kepada masyarakat, dan membawa ajaran Monoteistik Islam terserap dan tersebar ke daerah-daerah pinggiran. Ulama juga menghubungkan masyarakat desa dengan budaya nasional dan international ${ }^{4}$.

Proses Islamisasi yang terjadi di Sulawesi Selatan sejak masuknya Islam pada tahun 1605, sebagaimana disebutkan bahwa awal kedatangan Islam secara terang-

\footnotetext{
${ }^{1}$ Abu Dāud Sulaimān bin Al Asya’s Al Sijastānī, Sunan Abī Dāud, Juz 5, (Bairūt: Dār Al Kitāb Al Arābī, 2009), h.109

${ }^{2}$ Abi al Husain Ahmad bin Fāris bin Zakaria, Mu'jam Maqaȳ̄s Al-Lugah, (Cet. I; Bairut: Dār Uhyā al-Turāṡ Al Arabi, 2001), h. 663.

${ }^{3}$ Depertemen Pendidikan Nasional, Kamus Besar Bahasa Indonesia, (Jakarta: Pusat Bahasa, 2008), h.1774.

${ }^{4}$ Abd.Kadir Ahmad, Ulama Bugis, (Makassar: Indobis Publishing, 2008), h. 1-2.
} 
terangan di wilayah Sulawesi Selatan di bawah oleh tiga dai yang berasal dari Minangkabau yang terkenal dengan Datu' Tellue. Mereka Adalah: Abdul Qadi Datuk Tunggal dengan julukan Datuk ri Bandang, Sulung Sulaeman sebagai Datuk Patimang, dan Khatib Bungsu sebagai Datuk Ritiro. ${ }^{5}$

Selain tiga dai dan ulama pelopor Islam di Sulawesi Selatan ini, raja-raja Muslim pun memberikan sumbangsi yang begitu besar, sebut saja raja Gowa Bone La Tenri Ruwa yang tiga bulan setelah dilantik menjadi raja Bone menerima ajakan koleganya yaitu Sultan Alauddin untuk memeluk Islam, dan selanjutnya mengajak rakyatnya untuk menerima Islam sebagai agama resmi. ${ }^{6}$

Seperti itulah upaya penyebaran Islam dan manjadi agama panutan resmi rajaraja serta masyarakat, pada tahap awal yang sangat sederhana, dapat dikatakan Islam batin, hanya sekadar formal, namun belum aplikatif, atau pemahaman agama terutama pada tahap akidah belum maksimal dan mendalam.

Sebagaimana wilayah lainnya di Indonesia, Makassar diwarnai oleh kehidupan yang penuh dengan kesufian dan tarekat dan memang Islamisasi yang pertama sudah berbau Sufi. Kisah sufi selalu diwarnai dengan hal-hal yang ajaib atau kejadian yang luar biasa, hal yang sama terjadi ketika proses Islamisasi pertama di Makassar, dimana orangorang yang membawa Islam dilengkapi dengan hal-hal yang luar biasa. ${ }^{7}$

Di kecamatan Galesong Utara (termaksud suku Makassar) penduduknya 100 persen beragama Islam, tetapi mereka masih mempunyai kepercayaan nenek moyang, sebagaimana kutipan berikut:

Mereka percaya bahwa disekeliling mereka seperti gunung, di pohon-pohon, di sungai atau di lautan terdapat kekuatan-kekuatann gaib yang tidak dapat dihadapi oleh kekuatan manusia. Kekutan-kekutan gaib ini sewaktu-waktu dapat marah dan mengancam kehidupan manusia. Oleh karena itu mereka berusaha supaya kekuatan-kekuatan gaib yang berada di sekelilingnya dapat memberi ketenangan hidup baginya.

Mereka berusaha mengharmoniskan hidupnya dengan kekuatan gaib tersebut. Untuk mencapai keharmonisan ini mereka mengadakan upacara-upacara mereka mempercayai bahwa dengan upacara itu kekuatan-kekuatan gaib tersebut menjadi tenang dan diharapkan akan memberikan ketenangan dan kesejahteraan masyarakat Galesong Utara. ${ }^{8}$

Kondisi seperti ini bertahan terus dalam kehidupan masyarakat Makassar, bahkan sampai sekarang ini masih didapati, terutama dalam kehidupan masyarakat desa.

Secara umum, keadaan umat Islam ketika itu dapat dikatakan masih bergelimang dalam kemusyrikan dan kejahiliyahan diselimuti takhayyul, bi'dah-bi'dah, dan khurafat. Kehidupan umat Islam pada umummnya masih dikendalikan oleh

${ }^{5}$ A. Matullada, Sejarah Masyarakat dan Kebudayaan Sulawesi Selatan, (Makassar: Hasanuddin University Press, 1998), h. 150.

${ }^{6}$ Hannabil Rizal, dkk., Profil Raja dan Pejuang Sulawesi Selatan, (Makassar: YAPMI, 2004), h. 114.

${ }^{7}$ Ilham Hamid, dkk, Matahari Pembaharuan di Serambi Madinah Menelusuri Tapak Sejarah Muhammadiayah Kota Makassar, (Makassar: Majelis Pustaka PDM Kota Makassar dan LSQ Makassar, 2015), h. 69.

${ }^{8}$ Ilham Hamid, dkk, Matahari Pembaharuan di Serambi Madinah menelusuri Tapak Sejarah Muhammadiyah Kota Makassar, h. 70-71. 
pangaddakang/pangadereng ${ }^{9}$ yang bebasis dan bertumpuh pada hal yang disebut sebagai gaukang dan kalompoang ${ }^{1}$.

Dalam bidang pendidikan, sama sekali belum memiliki lembaga pendidikan modern yang ditandai dengan sistem klasikal, ada kurikulum, dan ada proses pembelajaran yang teratur. lembaga pendidikan tradisional yang ada hanyalah lembaga pendidikan mangaji tudang ${ }^{1}$ untuk mempelajari al Quran.

Transformasi ilmu pengetahuan keagamaan lainnya, seperti thahara, belajar shalat, belajar paraele (kewarisan), dan sebagainya lebih banyak dilakukan melalui keluarga atau melalui guru tarekat atau melalui Daengta Kalia, Daeng Imang (Qadhi), dan petugas parewa sara (perangkat syariat) lainnya. ${ }^{1}$

Bersama dengan berjalannya waktu penyebaran Islam terus mengalami perkembangan, gerakan dakwah pun mulai bermunculan, gerakan-gerakan tersebut umumnya terbagi dalam dua golongan yaitu gerakan modernis dan reformis. Yang dimaksud dengan reformis adalah gerakan yang menggunakan organisasi sebagai alat perjuangannya, disamping gerakan ini menggunakan organisasi sebagai alat perjuangannya, juga berusaha memurnikan Islam dan membangun kembali Islam dengan pikiran-pikiran baru, sehingga Islam dapat mengarahkan dan membimbing umat manusia dalam kehidupan mereka, misalnya: Muhammadiyah dengan melahirkan banyak tokoh di antaranya KH Fathul Muin Dg Maggading. Ia merupakan salah satu ulama kharismatik diera tahun 1960an sampai 1980an yang dikenal dengan aktivitas dakwah dan ceramahnya di sebuah masjid yang bernama Ta'mirul Masājid yang berlokasi di jalan Banda kota Makassar. ${ }^{1}$

Tulisan ini membahas tentang pemurnian ajaran Islam dengan melakukan studi terhadap pemikiran KH Fathul Muin Dg Maggading.

\section{KAJIAN TEORETIK}

Pemurnian dalam kamus bahasa Indonesia berasal dari kata munri yang artinya tidak becampur dengan unsur-unsur lain (tulen). Pemurnian berarti proses atau tindakan memurnikan sesuatu dari yang mengotorinya supaya menjadi bersih. ${ }^{1}$

Tajdīd sendiri dalam bahasa Arab secara etimologi yaitu menjadikan sesuatu menjadi baru, atau memperbaharui sesuatu. ${ }^{1}$ Tajdīd adalah lawan ${ }^{5}$ dari kata lama, sebagaimana ketika seseorang mengatakan orang itu memperbaharui sebuah urusan, artinya mengadakan kembali setelah lama ditinggalkan. ${ }^{1}$ Oleh karena itu, tajdīd secara

\footnotetext{
${ }^{9}$ Pangadakkang (Makassar) Pangngadereng (Bugis) berarti sistem pranata sosial yang berisi kitab undang-undang dasar tertinggi orang Bugis Makassar, lihat; Ilham Kadir, http://ilhamkadirmenulis.blogspot.co.id/2013/04/syariat-islam-di-sulsel-sebuah,pranata.(17Oktober 2016).

${ }^{1}$ Kalompoang/gaukang artinya Karaeng (tuan), lihat: Anwar Thosibo, Historiografi Perbudakan Sejarah Perbudakan di Sulawesi Selatan Abad XIX, (Magelang: Indonesia TeraI, 2001), h. 26.

${ }^{1}$ Mengaji tudang artinya pengdjian dengan Halaqo, lihat; http://www.uin-alauddin.ac.id/uin-124.html, (17 Oktober 016).

${ }^{1}$ Mustari Bosra dkk, Menepak Jejak Menata Langkah Sejarah Gerakan dan Biografi Ketua-Ketua Muhammadiyah Sulawesi Selatan, (Cet. I; Yogyakarta: Suara Muhammadiyah, 2015), h. 21.

${ }^{1}$ Mustafa Kamal Pasha, Ahma3d Adaby Darban, Muhammadiyah sebagai Gerakan Islam Dalam Perspektif Hostoris dan Ideologis, (Cet. I; Yogyakarta: Lembaga Pengkajian dan Pengalaman Islam (LPPI), 2000), h. 55.

${ }^{1}$ Tim Penyusun, Kamus Besar Bahasa Indonesia, (Jakarta: Balai Pustaka, 1989), h. 601.

${ }^{1}$ Al Imām Al Allāmah Abu Al5Fadl Jamāl Al Dīn Muhammad bin Mukrim bin Mazur Al Ifriqī Al Misrī, Lisān Al Arab, Juz 2, (Bairūt: Dār Sādir, t. tahun), h. 202.

${ }^{1}$ Al Ālim Al Allāmah Ahmad bin Muhammad bin Ali Al Faiwamī Al Maqrī, Misbāh Al Mun Al Mun̄̄r, (Bairūt: Maktabah Libanon, 1987), h. 92.
} 
bahasa bisa juga diartikan sebagai sesuatu yang pernah ada akan tetapi tidak nampak diakibatkan oleh sebab-sebab tertentu, ketika ia dikembalikan lagi seperti semula sebelum terjadinya perubahan, maka hal ini disebut dengan pemurnian. ${ }^{1}$

Secara terminologi tajdīd memiliki beberapa makna diantaranya; Menghidupkan kembali amalan yang sesuai dengan al-Quran dan al-Sunnah, setelah lama tidak dilaksanakan, serta menyerukan untuk kembali kepada keduanya ${ }^{1}$. Adapun orang-orang yang melakukan tajdīd disebut mujaddid, Al Maudūdī mengatakan mujaddid adalah setiap orang yang kembali menghidupkan syiar-syiar agama Islam setelah lama ditinggalkan, dan mengokohkannya kembali setelah lama terputus. ${ }^{1}$

Pemurnian dalam istilah Islam juga berarti menghidupkan kembali rambu-rambu Islam dan menegakkan kembai pilar-pilar Islamiyah agama ini dengan menjaga nashnash yang shahih secara bersih, dan membersihkan agama ini dari bi'dah dan penyimpangan yang mengotori, baik dalam bidang Nazhariyah (pemikiran), Amaliyah (ibadah) maupun bidang Sulukiyah (prilaku akhlak). ${ }^{2}$

Dalam konsep Muhammadiyah pembaharuan bisa juga berarti pemurnian, oleh karena itu kata tajdīd yang berarti pembaharuan harus dipandang menurut sasarannya:

Pertama: Berarti pembaharuan dalam arti mengembalikan kepada keasliannya/kemurniannya, ialah bila tajdīd itu sasarannya mengenai soal-soal prinsip perjuangan yang sifatnya tetap/tidak berubah-ubah.

Kedua: Berarti pembaharuan dalam arti modernisasi, ialah bila tajdīd itu sasarannya mengenai masalah seperti: metode, sistem, teknik, strategi, taktik perjuangan, dan lain-lain yang sebangsa itu, yang sifatnya berubah-ubah, disesuaikan dengan situasi dan kondisi/ruang dan waktu.

Tajdīd dalam kedua artinya, itu sesungguhnya merupakan watak dari pada ajaran Islam itu sendiri dalam perjuangannya. Dapat disimpulkan bahwa pembaharuan itu tidaklah selamanya berarti memodernkan, akan tetapi juga memurnikan, membersihkan yang bukan ajaran. ${ }^{2}$

Hal ini senada dengan apa yang telah menjadi keputusan Majelis Tarjih Muhammadiyah dalam Muktamar XXII, 1989 di Malang yang merumuskan makna tajdìd sebagai berikut:

Dari segi bahasa, tajd̄̄d berarti pembaharuan; dan dari segi istilah, tajdīd memiliki dua arti, yakni: (1) Pemurnian, dan (2) Peningkatan, pengembangan, modernisasi dan yang semakna dengannya.

Pemurnian sebagai arti tajdīd yang pertama, dimaksudkan sebagai pemeliharaan matan ajaran Islam yang berdasarkan dan bersumber kepada al-Quran dan Sunnah Shahīhah (Maqbūlah).

Sedangkan arti peningkatan, pengembangan, modernisasi dan yang semakna dengannya, tajdīd dimaksudkan sebagai penafsiran, pengamalan, dan perwujudan ajaran Islam dengan tetap berpegang teguh kepada Al-Quran dan Sunnah Shahīhah.

\footnotetext{
${ }^{1}$ Busțāmī Muhammad Saīd, Mafhūm Tajdīd Al Dīin, (Cet. III; Jeddah: Markaz Al Ta'ṣ̄l li Al Dirāsāt wa Al Buhūs̀, 1436H/2010M), h. 15.

${ }^{1}$ Muhammad Abdul Raūf Al Munāwī, Faid Al Qad̄̄r Syarh Al Jāmi' Al Soghīr, Juz 1, (Cet. II; Bairūt: Dār Al Ma'rifa, 1391 H/1972 M), h. 14.

${ }^{1}$ Abu Al A'lā' Al Maudūdī, Mūjaz Tārīkh Tajdīd al-Dīn wa Ihyāuhu wa Waqi' Al Muslimina wa Sabīl Al Nuhūd Bihim, (Cet. II; Libanon: Dār Al Fikr Al Hadīì, 1386 H/ 1967 M), h. 13.

${ }^{2}$ Agus Hasan Bashari, Mewaspadai Gerakan Kontekstualisasi al-Quran, (Surabaya: Pustaka asSunnah, 2003), h. 35.

${ }^{2}$ Majelis Tarjih dan ${ }^{1}$ Tajdid Pimpinan Pusta Muhammadiyah, Sejarah, http://tarjih.muhammadiyah.or.id. (12 Oktober 2016).
} 
Tajdīd dalam arti pemurnian (purifikasi) menyasar pada tiga sasaran, yaitu:

1. I'ādah atau pemulihan; yaitu membersihkan ajaran Islam yang tidak murni lagi.

2. Ibānah atau memisahkan; yaitu memisah-misahkan secara cermat oleh ahlinya, mana yang Sunnah dan mana pula yang bid'ah.

Ihyā' atau menghidup-hidupkan; yaitu menghidupkan ajaran-ajaran Islam yang belum terlaksana atau yang terbengkalai. ${ }^{2}$

Sejarah Islam mengenal gerakan-gerakan sejarah yang muncul dalam rangka purifikasi (pemurnian) agama. Pertama kali adalah gerakan Hanbalī ${ }^{2}$ yang dipelopori oleh Abū Muhammad al-Barbahārī. ${ }^{2}$ Dengan kata lain, ia dîpandang sebagai pelopor gerakan puritan pertama dalam sejarah Islam. Situasi masyarakat ketika itu ditandai dengan beberapa penyimpangan. Pertama, pernyimpangan aqidah telah melanda ummat Islam, kerena pengaruh filsafat Yunani yang kemudian muncul dalam masyarakat Islam dalam bentuk ilmu kalam dan falsafah.

Kedua, bi'dah dan khurafat juga menjamur di kalangan ummat Islam, sehingga timbul upacara-upacara ritual yang tidak berpangkal pada ajaran Allah dan Nabi. Penyimpangan seperti ini dilakukan oleh Syi'ah. ${ }^{2}$

Gerakan-gerakan pemurnian yang ada, apakah itu di Arab ataupun di Indonesia, kesemuanya memiliki tujuan akhir yang sama. Perbedaannya hanyalah corak pemurnian dan metode perubahan yang ditempuh. Setelah al-Barbahāri dari generasi ke generasi tokoh-tokoh pemurnian Islam terus bermunculan.

Lahirnya gerakan pembaharuan di Indonesia pada abad ke 19 dan 20 masehi, tidak dapat dipisahkan dari perkembangan Islam di Timur Tengah, khususnya seperti Mekkah sebagai Tanah Suci ummat Islam. Setiap tahun, khususnya pada bulan Haji seluruh ummat Islam yang mampu datang ke Tanah Suci ini dari berbagai penjuru dunia termaksud Indonesia, guna melaksanakan ibadah Haji, rukun Islam yang kelima. ${ }^{2}$

Pada waktu itu di Timur Tengah angin pembaharuan Islam yang dipelopori tokoh-tokoh pembaharuan Islam, seperti Syekh Muhammad bin Abdul Wahhab, Sayyed Jamaluddin Al Afgani, Muhammad Abduh, Muhammad Rasyid Ridha, Syekh Ahmad Khatib, semua tokoh-tokoh pembaharuan ini mengambil inspirasi dari Ibnu Taimiyah. ${ }^{2}$

Gerakan pembaharuan Islam di Indonesia dimulai ketika haji Miskin dan kawankawannya pulang dari Mekkah dengan membawa dan menyebarkan paham pemurnian agama ke daerah asal merka, yaitu Minangkabau. Gerekan mereka ini kemudian dikenal dengan "Gerakan Paderi" yang menimbulkan pengaruh besar bagi kehidupan sosial masyarakat Minangkabau. Gerakan Paderi ini pada masa selanjutnya, yaitu pada awal abad ke-20, dilanjutkan oleh gerakan Kaum Muda yang dipelopori antara lain oleh Syekh Muhammad Jamil Jambek, Haji Abdul Karim Amrullah, Haji Abdullah Ahmad, dan

\footnotetext{
${ }^{2}$ Mustafa Kamal Pasha, Ahmad Adaby Darban, Muhammadiyah sebagai Gerakan Islam Dalam Perspektif Hostoris dan Ideologis, h. $1 \mathrm{r} 7$

${ }^{2}$ Aliran fikih Islam yang dinisbahkan kepada Imam Ahmad Ibnu Hambal bin Hilai, Nama lengkap imam besar ini adalah Ahmad bin Hambal bin Hilal bin Usd bin Idris bin Abdullah bin Hayyan ibn Abdullah bin Anas bin Auf bin Qasit bin Mazin bin Syaiban. Ia terlahir di Baghdad Irak pada tahun 164 H/780 M. Lihat: Abdullah Mustafa Al-Maraghi, Pakar-Pakar Fiqih Sepanjang Sejarah, (Yogyakarta, LKPSM, 2001), h. 105.

${ }^{2}$ Salah satu pembesar mażhab Hanabilah, namanya adalah Abū Muhammad al-Hasan bin Alī bin Khalaf al-Barbāhārī. Lihat: Al- Imām Syamsuddīn Muhammad bin Ahmad bin Uṡmān al-Zahabī, Siyar alA'lām al-Nubalā', Juz 2, (Cet. XII; Bairūt: Muassasah al-Risālah, 2001), h. 90.

${ }^{2}$ Moh. Salim Aldjufri, Wahdáh Islamiyah di Gorontalo (Studi Tentang Corak Pemikiran dan Respon Masyarakat), (Jakarta: Kemetrian Agama RI, 2011), h. 47.

${ }^{2}$ Delier Noer, Gerakan Moderh Islam di Indonesia, (Jakarta: LP3S, 1996), h. 30.
} 
Syekh Muhammad Ibrahim Musa Parabek. Gerakan mereka tak hanya bersifat teologis tetapi juga bersifat sosial, diantaranya dengan mendirikan pesantren, madrasah, pengajian, penerbitan buku-buku dan majalah. ${ }^{2}$

Ada dua faktor yang menyebabkan tumbuh suatu kesadaran akan perlunya kebangkitan Islam. Pertama; faktor yang bersifat keagamaan yang lahir dari keprihatinan terhadap merosotnya rasa keimanan pada sebagaian besar kaum Muslim kala itu. Kedua; faktor yang bersifat politik yang muncul dari kebencian dan kekhawatiran terhadap ancaman pengaruh Barat yang terus mendesak. Di samping kedua faktor tersebut, mengalirnya imigran Arab dari Hadramaut yang membawa paham ortodoks tersebut berhasil pula meningkatkan kesadaran beragama umat Islam. ${ }^{2}$

\section{METODOLOGI PENELITIAN}

Penelitian ini adalah penelitian lapangan (field Research) yang bersifat kualitatif. Penelitian lapangan ini berhadapan dengan keluarga, murid langsung, dan para pemuda Muhammadiyah yang senantiasa bersama KH Fathul Muin Dg Maggading semasa hidup. Pendekatan yang digunakan adalah pendekatan historis, sosiologis dan filosofis. Sumber data primer dalam penelitian ini adalah buku hasil karya KH Fathul Muin Dg Maggading, Diktat pelajaran Keimanan 1 dan 2, Diktat Pelajaran Tafsir 1, Gerak Langkah Muhammadiyah Terlibat Dalam Kekaburan, melakukan observasi di kalangan keluarga dan para murid KH Fathul Muin Dg Maggading juga dengan merujuk pada agenda harian 1970 dan 1971. Sedangkan sumber sekunder adalah buku-buku yang menyangkut biografi ringkas KH Fathul Muin Dg Maggading, diantaranya: Matahari Pembaharuan di Serambi Madinah Menelusuri tepak sejarah Muhammadiyah Kota Makassar, Menepak Jejak Menata Langkah Sejarah Gerakan Dan Biografi Ketua-Ketua Muhamddiyah Sulawesi Selatan, dan terkhusus buku yang ditulis pada tahun 1966 berjudul Beginilah Muhammadijah Langkah dan Dharma Bakti Muhammadijah Tjab. Makassar. Data dikumpulkan melalui metode wawancara, observasi dan dokumentasi. Instrumen penelitian yang pada penelitian ini adalah dengan wawancara, wawancara mendalam, observasi, studi pustaka, dan data lokasi penelitian. Analisa data yang digunakan dalam penelitian ini adalah analisa data deduktif yang bertitik tolak dari pengetahuan umum tentang pemurnian ajaran Islam, kemudian mengambil kesimpulan yang bersifat khusus, setelah melakukan kajian mendalam terhadap pemikiran KH Fathul Muin Dg Maggading. Pekerjaan analisis data dalam hal mengatur, mengurutkan, mengelompokkan, memberi kode, dan mengkategorisasikan data yang terkumpul, baik dari catatan lapangan, gambar, foto atau dokumen berupa laporan.

\section{HASIL PENELITIAN DAN PEMBAHASAN}

Kata tajdīd menurut KH Fathul Muin Dg Maggading adalah pemurnian, untuk menyempurnakan pemurnian ini hanya bisa dicapai dengan cara kembali kepada ajaran al-Quran dan al-Sunnah. ${ }^{3}$ KH Fathul Muin Dg Maggading membagi konsep pemurnian menjadi tiga bagian yaitu pemurnian dalam bidang aqidah, ibadah, dan muamalah.

\footnotetext{
${ }^{2}$ Darul Aqsha, K.H. Mas Man̊sur (1896-1946): Perjuangan dan Pemikiran, (Jakarta: Erlangga, 2005), h. 9-10

${ }^{2}$ Daliar Noer, Gerakan Moderen Islam di Indonesia 1900-1942, h. 30-34

${ }^{3}$ Fathul Muin Dg Maggading, 'Gerak Langkah Muhammadijah Terlibat dalam Kekaburan, h. 1.
} 


\section{a. Pemurnian dalam Bidang Aqidah}

\section{Pengertian Aqidah:}

Secara etimologi, kata aqidah diambil dari kata dasar al-'aqdu yaitu al-rabth (ikatan), al-Ibrāmal-ihkām (pengesahan), (penguatan), al-tawaṡsiuq (menjadi kokoh, kuat), al-syaddu biquwwah (pengikatan dengan kuat), al-tamāsuk (pengokohan) dan aliśbātu (penetapan). Di antaranya juga mempunyai arti al-yaqīn (keyakinan) dan al-jazmu (penetapan).

$A l$-'Aqdu (ikatan) lawan kata dari al-hallu (penguraian, pelepasan). Dan kata tersebut diambil dari kata kerja: Aqadahu Ya'qiduhu (mengikatnya), Aqdan (ikatan sumpah), dan Uqdatun Nikah (ikatan menikah). Allah swt berfirman dalam Q.S. AlMāidah/5; 89 .

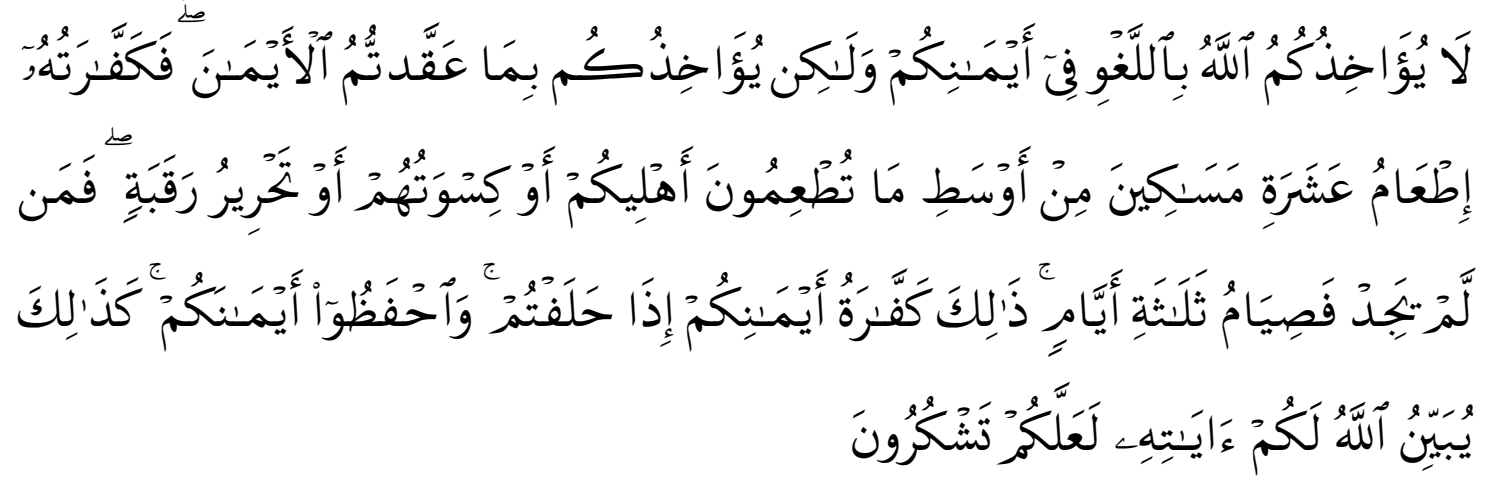

Terjemahnya:

Allah tidak menghukum kamu disebabkan sumpah-sumpahmu yang tidak dimaksud (untuk bersumpah), tetapi Dia menghukum kamu disebabkan sumpahsumpah yang kamu sengaja, Maka kaffarat (melanggar) sumpah itu, ialah memberi Makan sepuluh orang miskin, Yaitu dari makanan yang biasa kamu berikan kepada keluargamu, atau memberi pakaian kepada mereka atau memerdekakan seorang budak. barang siapa tidak sanggup melakukan yang demikian, Maka kaffaratnya puasa selama tiga hari. yang demikian itu adalah kaffarat sumpah-sumpahmu bila kamu bersumpah (dan kamu langgar). dan jagalah sumpahmu. Demikianlah Allah menerangkan kepadamu hukum-hukum-Nya agar kamu bersyukur (kepada-Nya). ${ }^{3}$

Aqidah secara terminologi yaitu perkara yang wajib dibenarkan oleh hati dan jiwa menjadi tenteram karenanya, sehingga menjadi suatu kenyataan yang teguh dan kokoh, yang tidak tercampuri oleh keraguan dan kebimbangan.

Aqidah Islamiyyah maknanya adalah keimanan yang pasti teguh dengan Rububiyyah Allah swt, Uluhiyyah-Nya, para Rasul-Nya, hari Kiamat, takdir baik maupun buruk, semua yang terdapat dalam masalah yang ghaib, pokok-pokok agama dan apa yang sudah disepakati oleh Salafush Shalih dengan ketundukkan yang bulat kepada Allah swt baik dalam perintah-Nya, hukum-Nya maupun ketaatan kepada-Nya serta meneladani Rasulullah saw. ${ }^{3}$ 2015), h. 122

${ }^{3}$ Kementerian Agama RI, Al-Qura'n dan Terjemahannya, (Cet. I; Jakarta: al-Hadi Media Kreasi,

${ }^{3}$ Abdullah bin Abdul Hamīd All-Atsarī, Al-Wajīz fì Aqīdah al-Salaf al-Shālih, (Ahli al-Sunnah wa al-Jamā'ah), (Cet. I; Riyadh, Dār al-Rāya li Nasyr wa al Tauzī’, 1418 H), h. 17-19. 


\section{Landasan Pemurnian Ajaran Islam KH Fathul Muin Dg Maggading dalam bidang Ibadah}

Pembahasan paling penting dalam permasalah pemurnian aqidah dalam pemikiran KH Fathul Muin Dg Maggading terinspirasi dari QS. Al-Fātihah/1: 1-3

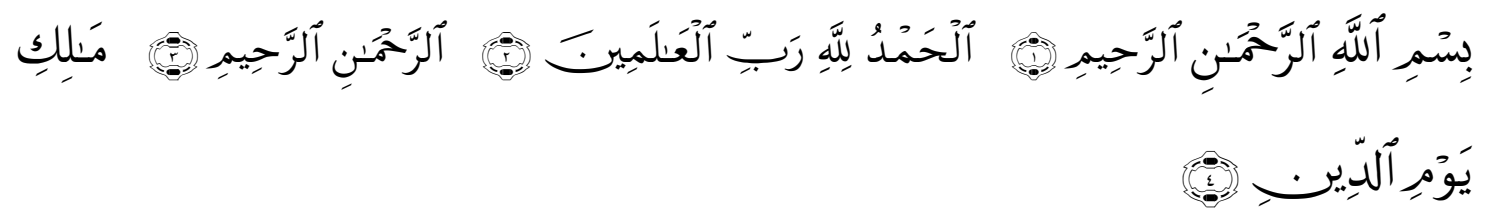

Terjemahnya:

Dengan menyebut nama Allah yang Maha Pemurah lagi Maha Penyayang. Segala puji bagi Allah, Tuhan semesta alam. Maha Pemurah lagi Maha Penyayang. Yang menguasai hari Pembalasan.

Ayat-ayat ini adalah pondasi penting kehidupan seorang Muslim, mulai dari menanamkan keyakinan dalam hati akan kekuasaan Allah, sampai pada meyakini bahwa sistem hidup yang terbaik adalah aturan-aturan Allah swt.

Inilah yang menunjukkan diantara fokus pembahasan pemurnian dalam bidang ibadah KH Fathul Muin Dg Maggading adalah menjelaskan tentang kekaburan akan fungsi rujukan utama ummat Islam yaitu al-Quran dan al-Sunnah.

Menurutnya, hanya dengan al Quran dan al-Sunnah, ummat ini akan menemukan jalan yang benar (siratul Mustaqīm) yang akan membawa kehidupan bahagia (Dienul Islam). Kehidupan yang teratur, terarah, terpimpin, yang berdasarkan hukum ciptaan Allah swt. ${ }^{3}$ Ini jelas dalam firman ÄAllah, Q.S. al-A'rāf/7: 96.

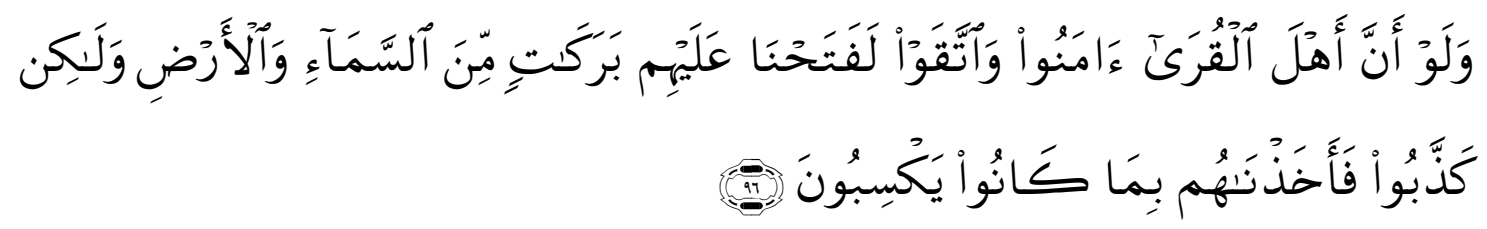

Terjemahnya:

Jikalau Sekiranya penduduk negeri-negeri beriman dan bertakwa, pastilah Kami akan melimpahkan kepada mereka berkah dari langit dan bumi, tetapi mereka mendustakan (ayat-ayat Kami) itu, Maka Kami siksa mereka disebabkan perbuatannya. $^{3}$

Baginya, ummat Islam tidak perlu bersusah payah untuk mencari falsafah hidup baru. Ajaran ummat Islam sudah sangat lengkap dengan adanya dua pondasi terkuat, yaitu al-Quran dan al-Sunnah.

\section{Tanda Baiknya Aqidah Menurut KH Fathul Muin Dg Maggading}

Aqidah sebagai pondasi keIslaman, harus terpatri dalam hati ummat Islam, yang dengannya ummat ini melakukan segala aktivitas kehidupannya. Dalam pandagan $\mathrm{KH}$ Fathul Muin, yang dimaksud dengan iman yang kuat dan murni kepada Allah, Rasul, firman-Nya, dan sabda Rasul-Nya, undang-undang, hukum-hukumNya (al-Quran dan alSunnah) adalah dengan cara meninggalkan segala sesuatu yang tidak sesuai, tidak sejalan

\footnotetext{
${ }^{3}$ Fathul Muin Dg Maggading, 'Diktat Peladjaran Keimanan 1, (t.cet, t.p, 1970), h. 4

${ }^{3}$ Kementerian Agama RI, Al-Qura'n dan Terjemahnya, h. 163
} 
bahkan bertentangan, bertolak belakang dari ketentuan Allah, Rasul, al-Quran dan alSunnah. Kiyai menjelaskan:

Untuk itu, segala sesuatu yang tidak cocok, tidak sesuai, menyimpang, bertolak belakang, menyalahi bahkan bertentangan dengan hukum Allah, sekalipun itu atas nama madzhab ${ }^{3}$, tariqat, tasawwuf, ulaḿna, ijma' ulama, pendapat gurutta, adat kebiasaan, adat orang dulu, hukum nenek moyang, filsafat, dan analogi-analogi, ilmu pengetahuan, sistem kehidupan dan kebudayaan baik dari Timur ataupun dari Barat, baik proggresip maupun modern, harus ditinggalkan.

Ia mempertegas dengan mengatakan: Jauhi madzhab, sebab inilah yang memecah belah ummat hingga bergolong-golongan yang mencerai-berikan ummat sehingga bentrok terus menerus satu sama lain. Buang tarekat dan mazhab sebab inilah sumber malapetaka kelemahan dan keruntuhan Islam. ${ }^{3}$

Lebih lanjut, ia menyebutkan beberapa ayat sebagai seruan kepada ummat Islam untuk kembali memurnikan dan membulatkan keimanan sesuai dengan apa yang telah Allah swt tentukan. Q.S. Al-Baqarah/2: 135-137.

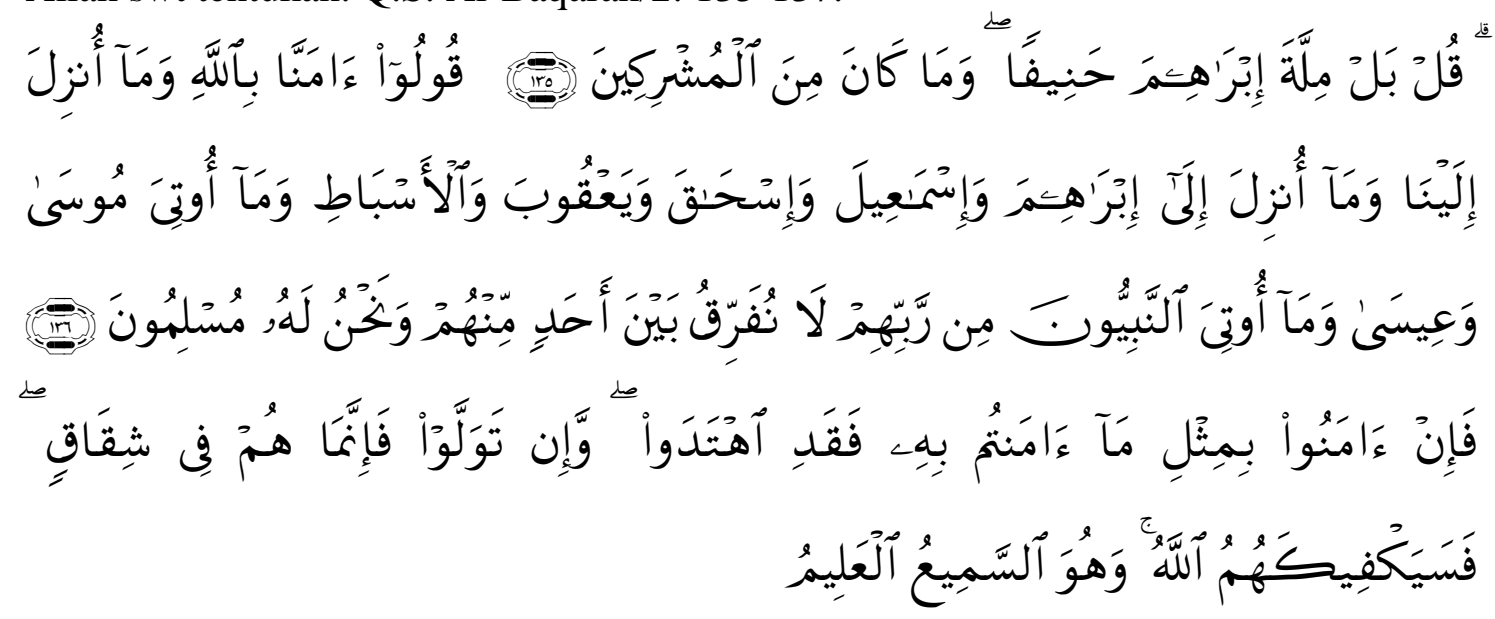

Terjemahnya:

Katakanlah hai Muhammad bahkan pasti bahwa millah (cara hidup) Nabi Ibrahim itulah yang lurus, bersih, jauh dari pada sesuatu diluar wahyu Allah.

Katakanlah, kami semua beriman pada Allah dan wahyu yang diturunkan pada Nabi-Nabi, Ibrahim, Ismail, Ishaq, ya'qub dan keturunannya, dan jugaberiman pada wahyu yang diturunkan pada Nabi Musa (Taurat) dan Nabi Isa (Injil) dan segala wahyu yang diterima oleh semua Nabi-Nabi Allah, tidak kami ingkar satupun, malahan setiap saat siap untuk melaksanakannya.

Maka sekiranya keimanan mereka sama dengan iman kamu sekalian (Rasul dan sahabat-sahabatnya) pastilah mereka akan dipimpin. Sebaiknya bila mereka menyalahi iman kamu (yaitu menyeleweng meninggalkan Quran wahyu) maka

\footnotetext{
${ }^{3}$ Secara bahasa, mazhab memifiki dua pengertian, pertama kata mazhab berasal dari kata zahabayazhabu yang memiliki arti telah berjalan, telah berlalu, telah mati. Pengertian kedua yakni, mempunyai arti suatu yang diikuti dalam berbagai masalah disebabkan adanya pemikiran, oleh karena itu mazhab berarti yang diikuti atau dijadikan pedoman atau metode.

Secara istilah, Madzhab adalah hasil ijtihad seorang imam (mujtahid) tentang hukum suatu masalah atau tentang kaidah-kaidah istinbath. Dengan demikian pengertian mazhab adalah: mengikuti hasil ijtihad seorang imam tentang hukum suatu masalah atau kaidah-kaidah istinbath-nya. Lihat: Dedi Supriadi, Perbandingan Mazhab dengan Pendekatan Baru, (Bandung: CV Pustaka Setia, 2008), h. 14.

${ }^{3}$ Fathul Muin Dg Maggading, Diktat Peladjaran Keimanan 1, h. 10.
} 
pastilah mereka hancur, pecah belah, berantakan. Maka untuk menghadapi golongan (madzhab, tarekat, pemecah agama) cukuplah Tuhanmu untuk engkau. Dialah yang Maha Mendengar dan Maha Tahu. ${ }^{3}$

Menurutnya beginilah aqidah, iman dan keyakinan yang benar yang diakui oleh Allah dan RasulNya, selainnya tertolak tidak berharga dan tidak bernilai disisi Allah swt. Hanya iman yang demikian ini dapat memperoleh bimbingan hidayah dari Allah pada kehidupan dunia dan akhirat.

\section{b. Pandangan KH Fathul Muin Dg Maggading tentang Al-Quran}

Dalam pandangan KH Fathul Muin Dg Maggading, ia memahami di antara urgensi al-Quran, adalah sebagai berikut;

1. Al-Quran adalah pedoman hidup seorang Muslim yang semestinya dijadikan fondasi kehidupan, karena dalam al-Quran, Allah telah menceritakan perjalanan kehidupan para Nabi, terkhusus Nabi Muhammad saw, sebagai bahan pelajaran bagi generasi setelahnya. Q.S. Al-Ahzāb/33: 21.

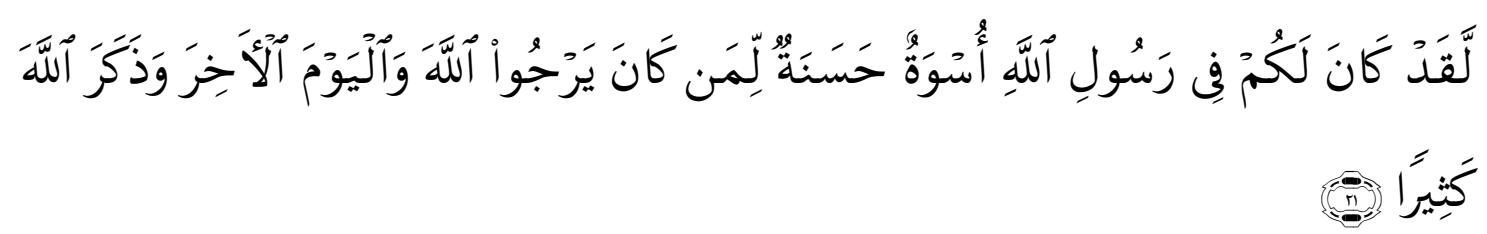

Terjemahnya:

Sesungguhnya telah ada pada (diri) Rasulullah itu suri teladan yang baik bagimu (yaitu) bagi orang yang mengharap (rahmat) Allah dan (kedatangan) hari kiamat dan dia banyak menyebut Allah. ${ }^{3}$

Sebagaimana al-Quran juga telah menjelaskan perjalanan orang-orang beriman sepanjang sejarah, bagaikan mata rantai yang akan terus sambung meyambung.Q.S. Yūsuf/12: 111.

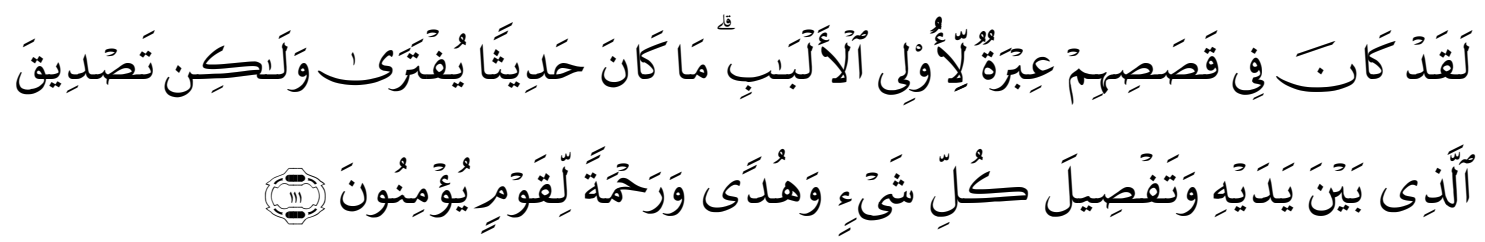

Terjemahnya:

Sesungguh adalah pada sejarah perjuangan mereka yang beriman dan sambungmenyambung mengandung gambaran bagi manusia yang mempunyai pikiran. Sejarah yang disusun oleh Allah swt dalam al-Quran ini tidaklah merupakan isapan jempol penuh dengan dusta dan tipuan. Sebaliknya adalah mengandung sematamata pembenaran dan pembetulan terhadap kejadian yang ada sebelumnya, yang merupakan tambahan pengetahuan serta penjelasan tentang akibat-akibat segaa sesuatu kejadian sejarah pula, merupakan pimpinan yang mengandung rahmat bagi kaum yang beriman. ${ }^{3}$

\footnotetext{
${ }^{3}$ Terjemahan KH Fathul Muin ${ }^{7}$ Dg Maggading, Diktat Peladjaran Keimanan 1, h. 10-11.

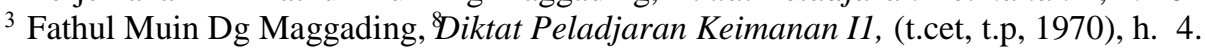

3 Fathul Muin Dg Maggading, ${ }^{9}$ Diktat Peladjaran Keimanan I1, h. 4.
} 
Selain menukil ayat di atas, ia kembali menegaskan akan perkara penting ini, dengan menyebutkan firman Allah swt. Q.S. Surah Hūd/11: 120:

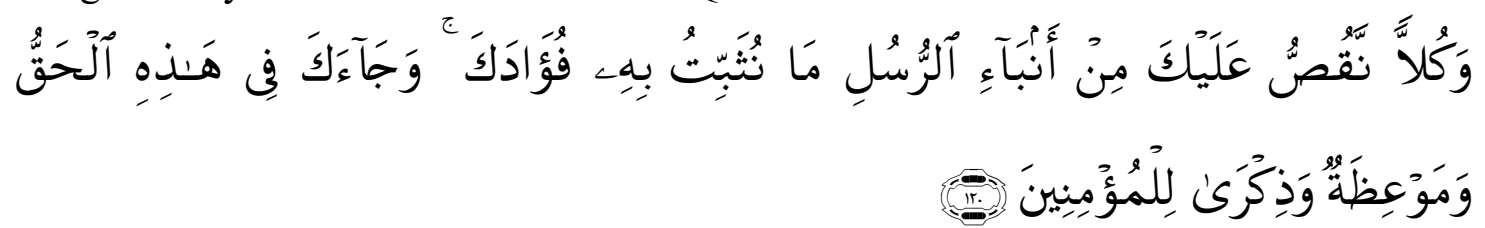

Terjemahannya:

Dan segala sesuatu dari pada sejarah para Nabi dan Rasul yang dapat memelihara jiwa jihad dan semangat berkorban telah kami lukiskan dalam al-Quran, sejarah yang membawa kebenaran, nasehat dan pelajaran komplit bagi kaum beriman. ${ }^{4}$

4. Hanya dengan bimbingan dan petunjuk Allah swt umat Islam akan sampai kepada siratal Mustaqim, dan yang ia maksud dengan siratal Mustaqim adalah al Quran alKarim. Artinya untuk menjalankan siratal Mustaqim yaitu kandungan daripada alQuran itu, membutuhkan bimbingan dan petunjuk dari Allah swt. Dalam buku diktat pelajaran keimanan 2, ia menjelaskan:

Untuk berada dalam jalan yang lurus, manusia memerlukan petunjuk dan pimpinan agar tidak tersesat di tengah jalan, sehingga ia dapat sampai pada akhirnya pada tujuan perjalanan, yaitu tegaknya hidup dan kehidupan seorang yang diridhai, disenangi oleh Allah swt.

Sampainya seseorang pada tujuan terakhir tentulah memerlukan petunjuk atau Hudan. Adapun petunjuk atau Hudan ini tidak lain daripada al-Quran. ${ }^{4}$

Statement ini diperkuat dengan menyebutkan beberapa ayat dari Q.S. surah alBāqarah/2: 2

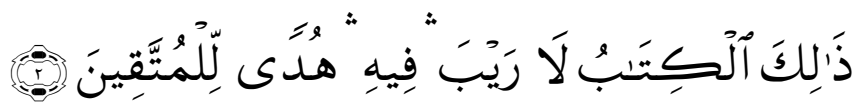

Terjemahnya:

"Inilah al-Quran tak ada syak di dalamnya, Hudan (petunjuk) bagi muttaqin". ${ }^{4}$

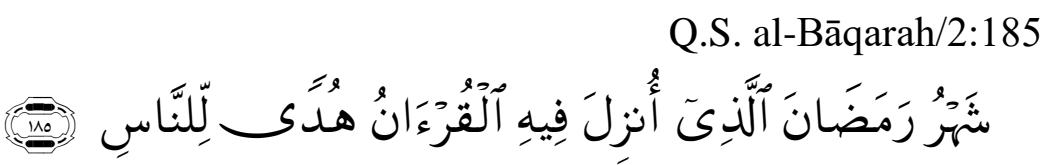

Terjemahannya:

"Bulan Ramadhan al-Quran diturunkan yang isinya merupakan hudan (Petunjuk) bagi manusia". 4

\footnotetext{
${ }^{4}$ Fathul Muin Dg Maggading, 9iktat Peladjaran Keimanan I1, h. 4.

${ }^{4}$ Terjemahan Fathul Muin Dg Maggading, Diktat Peladjaran Keimanan I1, h. 23.

${ }^{4}$ Tejemahan Fathul Muin Dg Maggading, Diktat Peladjaran Keimanan I1, h. 23.

${ }^{4}$ Tejemahan Fathul Muin Dg Maggading, Diktat Peladjaran Keimanan I1, h. 23.
} 
Q.S. al-Māidah/5: 15

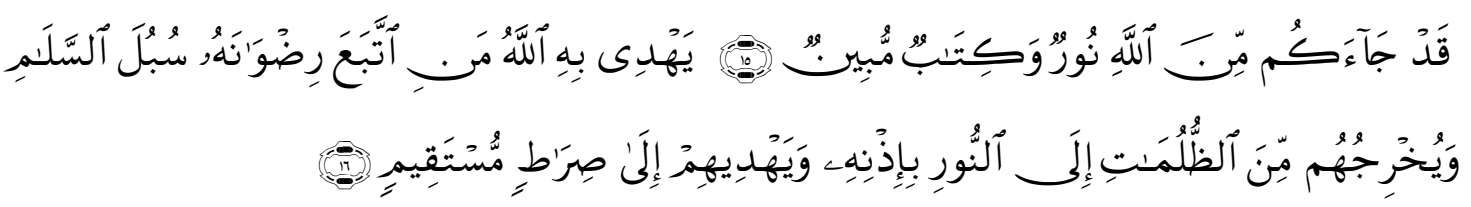

Terjemahnya:

Telah datang kepadamu cahaya yang terang berupa Kitab yang mengandung penjelasan. Dengan kitab itu, Allah memberi petunjuk orang yang menuruti ridhaNya menuju jalan hidup bahagia dan mengeluarkan mereka dari kegelapan kepada terang benderang, dengan izinNya dan kitab (al-Quran) itu memberi pimpinan kepada mereka kejalan yang lurus) ${ }^{4}$

Q.S. al-Syūra/42:52.

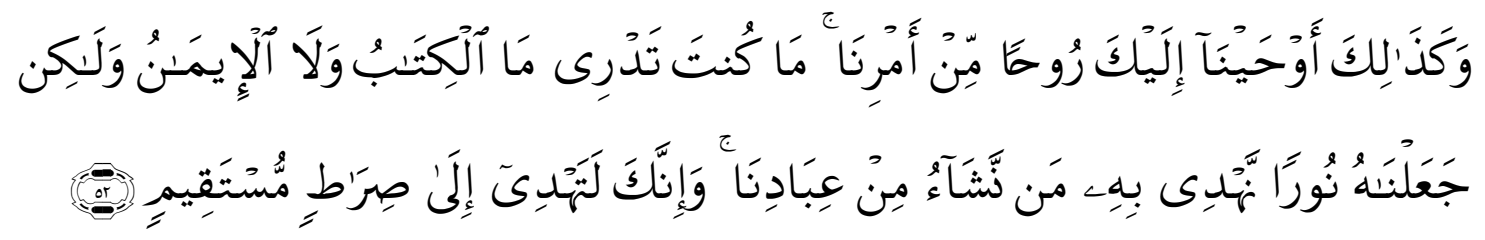

Terjemahnya:

Dan demikianlah Kami telah wahyukan kepadamu Quran ini sebagai suatu bahagian dari perintah/urusan Kami, sebelumnya tidaklah engkau tahu tentang Kitab dan tidak pula mengerti tentang Iman. Tetapi Kami (Tuhan) telah menjadikannya sebagai nur cahaya dan dengannya Kami tunjuki siapa yang Kami kehendaki di antara hamba-hambaKu. Dan sesungguhnya dengan nur cahaya itu pula engkau akan menunjukkan manusia pada jalan yang lurus. ${ }^{4}$

5. Ummat harus kembali memahami tujuan utama diturunkannya al-Quran.

Melihat kondisi yang begitu memprihatinkan terjadi, di mana al-Quran hanya sekedar menjadi hiasan kehidupan yang dibaca dengan suara indah akan tetapi kering dari praktik dalam kehidupan. Olehnya itu Kiyai menjelaskan dalam diktat tafsir 1 miliknya;

"Membaca al-Quran bukan saja memperbaiki lagu dan makhrajnya, tetapi selalu diusahakan mengamalkan apa yang telah dibaca dan diketahui". ${ }^{4}$

Karena hanya dengan menerapkan al-Quran ummat ini akan kembali kepada kejayaan, kehidupan yang teratur, sebagaimana yang telah dirasakan dalam kehidupan para sahabat Nabi saw. Q.S. Al-A'rāf/7:96.

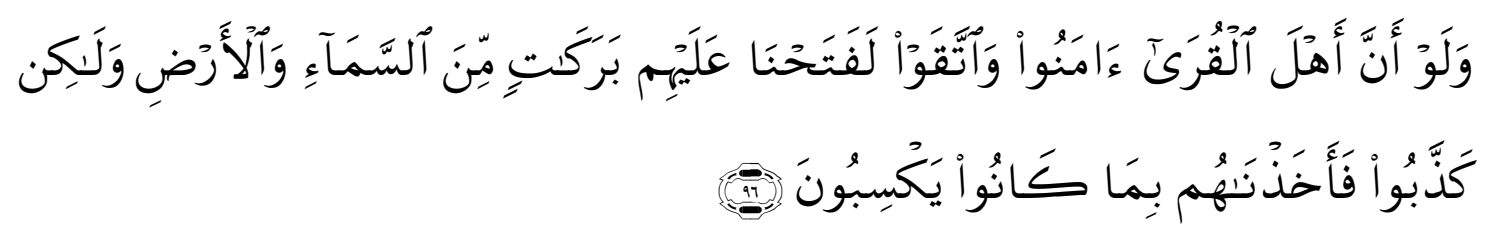

Terjemahnya:

\footnotetext{
${ }^{4}$ Tejemahan Fathul Muin Dg Maggading, Diktat Peladjaran Keimanan I1, h. 24.

${ }^{4}$ Tejemahan Fathul Muin Dg Maggading, Diktat Peladjaran Keimanan I1, h. 24.

${ }^{4}$ Fathul Muin Dg Maggading, Diktat Peladjaran Tafsir al-Quran 1 h. 7.
} 
Jikalau Sekiranya penduduk negeri-negeri beriman dan bertakwa, pastilah Kami akan melimpahkan kepada mereka berkah dari langit dan bumi, tetapi mereka mendustakan (ayat-ayat Kami) itu, Maka Kami siksa mereka disebabkan perbuatannya. $^{4}$

6. Al-Quran adalah landasan pendidikan anak-anak umat Islam.

Ia menyebutkan, bahwasanya setiap Muslim dituntut dan wajib untuk bermusābaqah (berlomba) dalam mengamalkan al-Quran dalam segala sisi kehidupan. Ia menjelaskan dengan menukil beberapa hadis Nabi saw, di antaranya:

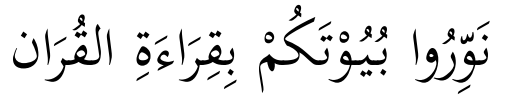

Artinya:

"Sinarilah Rumah-Rumah kalian dengan bacaan al-Quran".

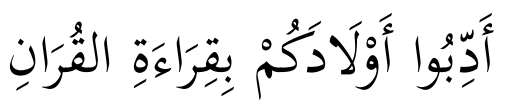

Artinya:

"Didiklah anak-anakmu dengan pelajaran al-Quran"

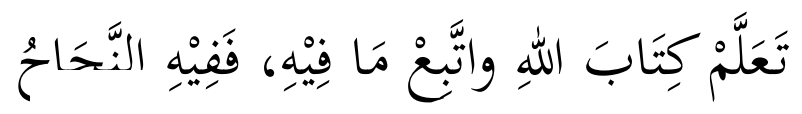

Artinya:

Pelajarilah al-Quran dan ikutilah ajarannya dan peraturan yang ada di dalamnya, maka ketaatan dan pengenalan yang ada di dalamnya membawa kepada keselamatan. $^{4}$

Dari penjelasan hadis di atas, jelaslah tergambarkan alur pemikiran kiyai mengenai urgensi mengajarkan al-Quran sejak dini. Bukan hanya cara membaca yang baik akan tetapi diajarkan memahami makna dan mengamalkan kandungannya. Sehingga kelak akan menjadi generasi yang berkepribadian al-Quran.

\section{Pandangan KH Fathul Muin Dg Maggading tentang Al-Sunnah}

Menurutnya, sunnah adalah pendamping al-Quran, dimana al-Quran tidak akan bisa dilaksanakan dengan baik kecuali dengan adanya sunnah Nabi saw. Hal ini sebagaimana yang disebutkannya, setelah memaparkan pentingnya kembali melaksanakan perintah al-Quran. Ia menuliskan:

Ajaran akan ayat al-Quran dijadikan masalah pengamalannya sebagai tujuan pokok. Berbetulan pula, bahwa segala segi kehidupan kita kesemuanya telah mendapat petunjuk dari al-Quran sekalipun dalam garis-garis besarnya dan dilengkapi petunjuk itu dengan al-hadis atau praktek Sunnah Rasul saw. ${ }^{5}$

\footnotetext{
${ }^{4}$ Kementerian Agama RI, Al-Q̄ura'n dan Terjemahnya, h. 163.

${ }^{4}$ Fathul Muin Dg Maggading, Diktat Peladjaran Tafsir al-Quran 1 h. 7.

${ }^{4}$ Fathul Muin Dg Maggading, ${ }^{9}$ Diktat Peladjaran Tafsir al-Quran 1, h. 8.

${ }^{5}$ Fathul Muin Dg Maggading, Diktat Peladjaran Tafsir al-Quran 1, h. 8
} 
Ia melanjutkan pemaparan akan pentingnya melaksanakan ajaran al-Quran dengan bimbingan sunnah Nabi saw, dengan menyebutkan sebuah ayat dari Q.S. AlZumar/39: 17-18.

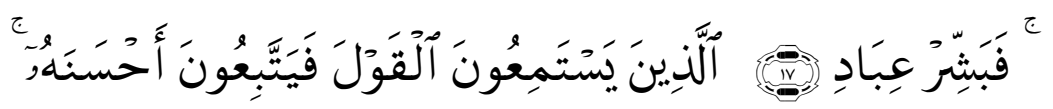

Terjemahnya:

Gembirakanlah hambaKu, yang patuh mendengarkan dan memperhatikan ayat-ayat Allah kemudian mengamalkannya dengan baik dan sempurna. ${ }^{5}$

Ia juga menyebutkan hadis Nabi saw:

Artinya:

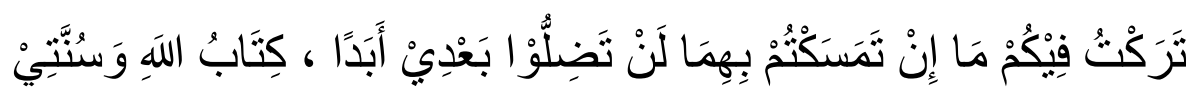

Aku Tinggalkan padamu sekalian dua hal yang penting, kamu takkan sesat (menjalani jalan buntu dalam kehidupan) selama kamu berpegang padanya, yaitu al-Quran dan Sunnah Rasul saw. ${ }^{5}$

2

\section{b. Pemurnian dalam Bidang Ibadah}

Ibadah menurut bahasa berarti patuh (al-țā'ah), dan tunduk (al-khuḍū'). Ubudiyah artinya tunduk dan merendahkan diri. Menurut al-Azhari, kata ibadah tidak dapat disebutkan kecuali untuk kepatuhan kepada Allah. ${ }^{5}$ Ibadah berasal dari kăta pengabdian yang memiliki kata dasar abdi atau hamba. Pengabdian adalah pekerjaan, dimana seorang abdi (hamba) melakukan pekerjaan untuk dipersembahkan kepada Tuhan yang disembahnya, inilah defenisi ibadah dalam arti luas.

KH Fathul Muin mendefenisikan kata pengabdian adalah seluruh pekerjaan, amal perbuatan seorang hamba yang ditujukan kepada TuhanNya melalui hukum-hukum yang disyariatkanNya dengan maksud memperoleh keridhaanNya. ${ }^{5}$

Dalam buku Gerak Langkah Muhammadijah terlibat dalam kekaburan, ia menjelaskan bahwasanya dalam mukaddimah anggaran dasar al-Fatihah atau yang lebih dikenal dengan Ummul Kitab mengandung tiga kerangka dasar yang menjadi tolak seluruh pikiran, tindakan, dan gerak langkah usaha manusia. Ketiga pondasi tersebut adalah:

1. Iman

2. Ibadah

3. Muamalah yang menyangkut way of life dalam segala segi kehidupan. ${ }^{5}$

Pemurnian dalam bidang ibadah ini menurut KH Fathul Muin diinspirasi dari muqaddimah anggaran dasar Muhammadiyah yaitu ayat ke-5 dari Surat al-Fatihah.

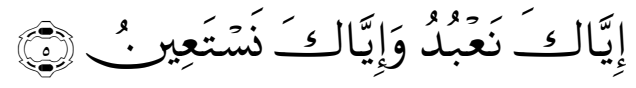

\footnotetext{
${ }^{5}$ Terjemahan Fathul Muin Dg Maggading, Diktat Peladjaran Tafsir al-Quran 1, h. 8.

${ }^{5}$ Terjemahan Fathul Muin Dg Maggading, Diktat Peladjaran Tafsir al-Quran 1, h. 8.

5 Amir Syarifudin, Garis-Garỉs Besar Fiqih, (Cet. II; Jakarta: Kencana, 2003), h. 17.

${ }^{5}$ Fathul Muin Dg Maggading, ${ }^{4}$ Diktat Peladjaran Keimanan II, h. 8

${ }^{5}$ Fathul Muin Dg Maggading, Gerak Langkah Muhammadijah Terlibat dalam Kekaburan, h. 1
} 
Terjemahnya:

Hanya Engkaulah yang Kami sembah, dan hanya kepada Engkaulah Kami meminta pertolongan. ${ }^{5}$

Ini adalah hasil yang tumbuh dari inplementasi ayat 1-4 al-Fatihah. Melalui ayatayat ini, seorang hamba akan menyatakan penyerahan diri yang sepenuhnya hanya kepada Allah swt. Keimanan dan keIslamannya berkonsekuensi kepada sumpah setia untuk melaksanakan lima dasar atau rukun Islam sebagai pondasi ibadah. Kelima pokok tersebut adalah:

1. Syahadatain

2. Shalatul Chans dan Shaltul Wustha

3. Zakat

4. Puasa pada bulan Ramadhan

5. Haji ke Baitullah ${ }^{5}$

Berangkat dari defenisi di atas, ia menyimpulkan pengabdian atau ibadah adalah:

Pertama: Pengabdian bertujuan untuk memperoleh ridha Allah.

Kedua: Pelaksanaan pengabdian harus mengikuti hukum-hukum dan peraturanperaturan yang telah ditetapkan atau disyariatkan. Dalam hal ini adalah mengikuti contoh penerapan Rasulullah saw, yang merupakan contoh terbaik dalam menjalankan syariat Islam. QS. Al-Zumar/39:10

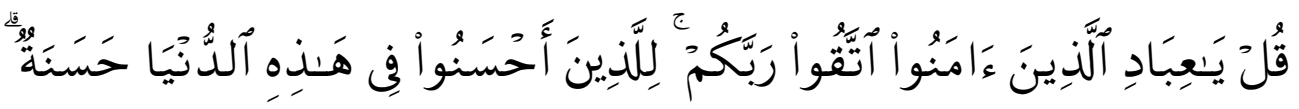

Terjemahnya:

Katakanlah hai Muhammad: Hai hamba-hambaKu yang beriman ikutlah hukum dan peraturan-peraturan Tuhanmu (bertakwalah). Asapun bagi mereka yang berlaku baik akan memperoleh ganajaran hasil baik sekarang di dunia. Zumar/39:17

Selain itu, hal yang senada juga dijelaskan oleh Allah dalam QS. Al-

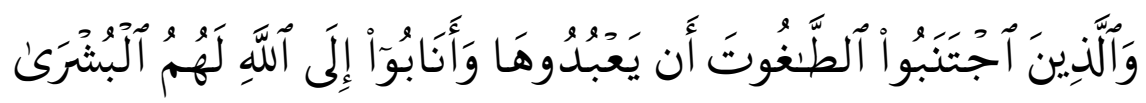

Terjemahnya:

Dan Mereka yang menjauhkan diri-diri mereka dari pada pengabdian kepada thagut-thagut (menuruti peraturan yang datangnya bukan dari Allah). Gembirakanlah hamba-hamba yang demikian itu. ${ }^{5}$

Ketiga: Pengabdian adalah inti tujuan diutusnya para Nabi dan Rasul, mulai dari Nabi Adam sampai Rasulullah Muhammad saw. Di dalam al-Quran sangat banyak ayatayat yang menyebutkan akan permasalahn ini, diantaranya; QS. Nuh/71: 1-3.

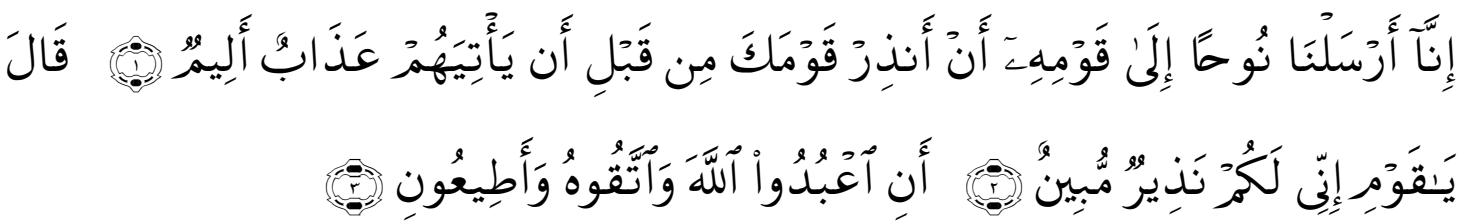

\footnotetext{
${ }^{5}$ Kementerian Agama RI, Al-Qura'n dan Terjemahannya, h. 1

${ }^{5}$ Fathul Muin Dg Maggading, 7 Gerak Langkah Muhammadijah Terlibat dalam Kekaburan, h. 5

5 Terjemahan Fathul Muin Dg Maggading, Diktat Peladjaran Keimanan II, h. 8
} 
Terjemahnya:

Kami telah mengutus Nuh kepada kaumnya dengan tugas pokok yaitu ancamlah dan takutilah mereka kaummu sebelum datangnya siksaan yang pedih. Nuh berkata: "Hai Kaumku sesungguhnya aku ini adalahpembawa ancaman dan penjelasan. Yaitu mengabdilah pada Tuhanmu dan taatilah hukum peraturanNya dan dalam hal ini ikutilah contoh-contoh pelaksanaan yang Kami akan sampaikan dan jelaskan.

QS. Hud/11: 50

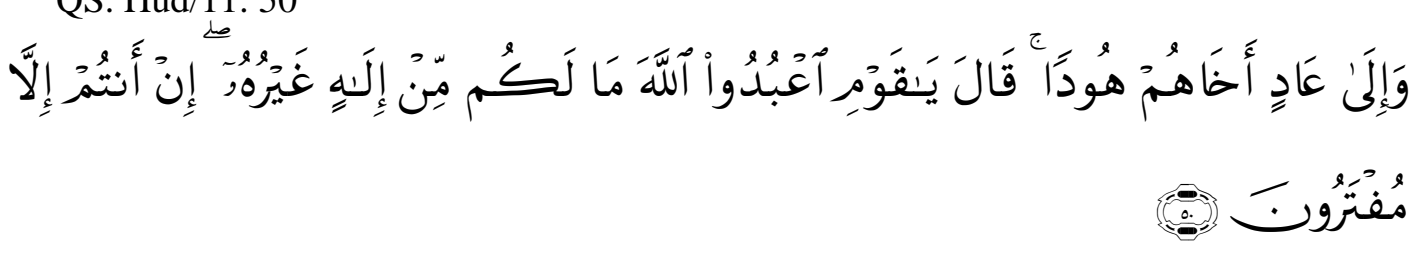

Terjemahnya:

Dan untuk kaum Ā'd, Kami telah mengutus Nabi Hud a.s. dengan tugas pokok yaitu" Hai kaumku mengabdilah kamu kepada Allah. Tak ada tempat mengabdi selain dari padaNya. Cara penyembahan yang kamu lakukan ini adalah hanya ciptaan-ciptaan (cara-cara yang kamu atur sendiri) yang kamu tentukan sendiri. ${ }^{5}$

Kelima: konsekuensi dari pengabdian ini, selain mengikuti hukum dan peraturan syariat yang ada, yang lebih penting adalah bagaimana mencontohi Rasulullah saw dalam pelaksanaannya. QS. Al-Hasyr/59: 7

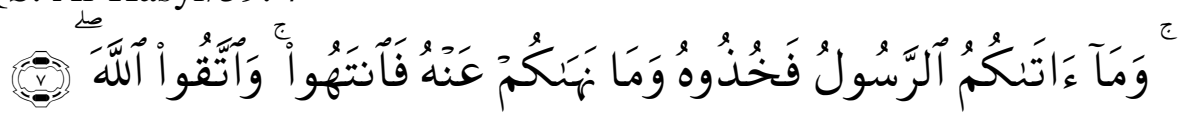

Terjemahnya:

Hukum dan peraturan apapun yang disampaikan (syariat) oleh Nabi Muhammad saw pada kamu, laksanakanlah dan apa saja yang dilarangnnya hentikanlah. ${ }^{6}$

Setelah menjelaskan akan pentingnya untuk kembali memurnikan ibadah kepada Allah. Ia mengakatan:

"Hukum Allah harus berjalan apapun yang akan terjadi. Peraturan harus diterapkan, senang atau susah, tegak menang ataupun hancur menjadi tanah."

Ia terinspirasi oleh QS. Al-Nisa'/4: 105-106

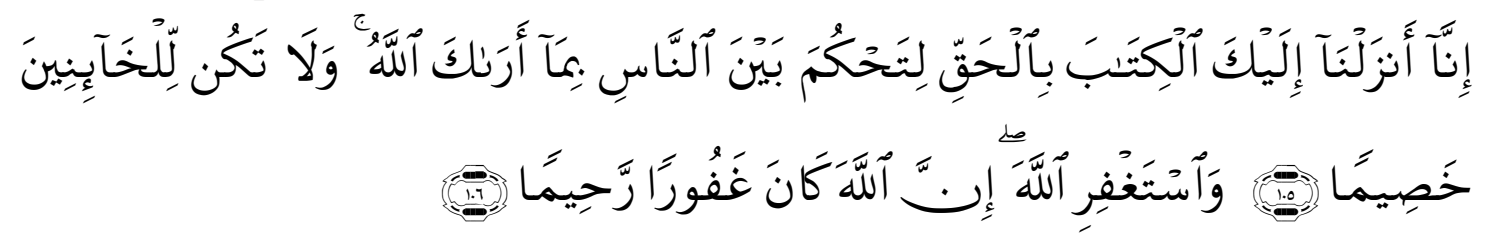

Terjemahnya:

Kami turunkan (adakan) kitab al-Quran ini kepadamu dengan berisi kebenaran (hukumnya tepat) agar kamu mengatur kehidupan manusia denganya sebagaimana yang diajarkan Allah kepadamu (keterangan pelaksanaannya) dan datanglah kamu menjadi pembela bagi penghianat-penghianat. ${ }^{6}$

Kiyai menegaskan yang di maksud dengan penghianat-penghianat dalam ayat adalah orang-orang yang mengaku beriman, akan tetapi dalam tata kehidupannya

\footnotetext{
${ }^{5}$ Fathul Muin Dg Maggading, ${ }^{9}$ Diktat Peladjaran Keimanan II, h. 9

${ }^{6}$ Fathul Muin Dg Maggading, Diktat Peladjaran Keimanan II, h. 10

${ }^{6}$ Fathul Muin Dg Maggading, Diktat Peladjaran Keimanan II, h. 13.
} 
mengikuti hukum dan peraturan yang bertentangan dengan peraturan al-Quran dan alSunnah Nabi saw.

\section{c. Pemurnian dalam Bidang Muamalah}

Muamalah diartikan sebagai hubungan kemasyarakatan, hubungan hidup antara manusia, serta perkembangan bermacam-macamnya sistem kehidupan yang berimplikasi kepada perbedaan corak dan cara kehidupan. ${ }^{6}$

Pemurnian ajaran Islam dalam bidang ibadah KH Fathumuin Dg Maggading terinspirasi dari dua ayat terakhir dari surah al-Fatihah

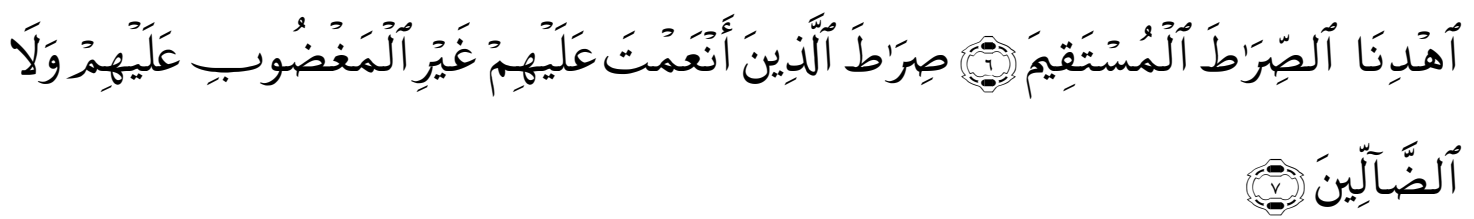

Terjemahnya:

Tunjukilah kami jalan yang lurus, (yaitu) jalan orang-orang yang telah Engkau beri nikmat kepada mereka; bukan (jalan) mereka yang dimurkai dan bukan (pula jalan) mereka yang sesat. ${ }^{6}$

Menurutnya, ayat ke enam ini berimplikasi bahwasanya setiap Muslim harus senantiasa berharap dalam pemilihan sistem kehidupan dan realisasinya mendapatkan petunjuk (hidayah) dan bimbingan dari Allah swt. Olehnya itu, ia menjelaskan akhir ayat ke tujuh surah al-Fatihah ini menunjukkan akan adanya sistem hidup di muka bumi ini. șirātallażina a'n amta a'laihim (bermakna way of life yang selamat) yaitu sistem hidup menurut ilmu Allah, dan tata tertib kehidupan yang telah terlaksana dan dialami oleh mereka yang telah mendapatkan karunia Allah swt.

Setelah itu ayat ke tujuh ini bermakna bahwasanya ummat Islam harus menghindarkan diri dari Way of Life al-Magḍūb a'laihim (yaitu way of life) yang diciptakan manusia itu sendiri, di mana kesemuanya berdasarkan, bertujuan, dan berjiwa materialisme. Kiyai menyebutkan di antara isme-isme yang bermunculan adalah:
1. Komunisme ${ }^{6}$
2. Naturalisme ${ }^{6}$
3. Sosialisme ${ }^{6}$
4. Individualisme ${ }^{6}$

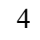
5
6

7

${ }^{6}$ Fathul Muin Dg Maggading, ${ }^{2}$ Gerak Langkah Muhammadijah Terlibat dalam Kekaburan, h.5

${ }^{6}$ Kementerian Agama RI, Al-Q̉ura'n dan Terjemahnya, h. 1

${ }^{6}$ Komunisme adalah sebuah ${ }^{4}$ ideologi. Penganut paham ini berasal dari manifest der kommunistischen yang ditulis oleh Karl Marx dan Friedrich Engels, https://id.wikipedia.org/wiki/Komunisme, (1 Januari 2016)

${ }^{6}$ Naturalisme mempunyai bebérapa pengertian, yaitu dari segi bahasa, Naturalisme berasal dari dua kata, "Natural" artinya "Alami" dan "Isme" artinya "Paham". Nature artinya alam atau yang dibawa sejak lahir. Aliran naturalisme dapat juga disebut sebagai "Paham Alami". Maksudnya, bahwa setiap manusia yang terlahir ke bumi ini pada dasarnya memiliki kecenderungan atau pembawaan yang baik dan tak ada seorangpun terlahir dengan pembawaan yang buruk. Lihat: Suparlan Suhartono, Filsafat Pendidikan, (Jogjakarta: Ar-Ruzz Media, 2007), h. 79.

${ }^{6}$ Secara etimologis, sosialismé berasal dari bahasa Latin "SOCIUS" yang berarti sahabat atau teman. Istilah ini merupakan suatu prinsip pengendalian harta dan produksi serta kekayaan oleh kelompok. Lihat: Lorens Bagus, Kamus Filsafat, (Jakarta: Gramedia, 1996), h. 1030-1032

${ }^{6}$ Individualisme merupakan satu filsafat yang memiliki pandangan moral, politik atau sosial yang menekankan kemerdekaan manusia serta kepentingan bertanggung jawab dan kebebasan sendiri. Seorang 
5. Kolektivisme ${ }^{6}$

8

Menurutnya semua isme-isme ini bermunculan diakibatkan oleh sistem berfikir manusia yang disebut filsafat, yang kemudian hari lebih diutamakan untuk menjadi landasan muamalah dari pada al-Quran. Inilah yang menjadi asal muasal terjadinya berbagai permasalah di muka bumi. QS.al-Rūm/30:41

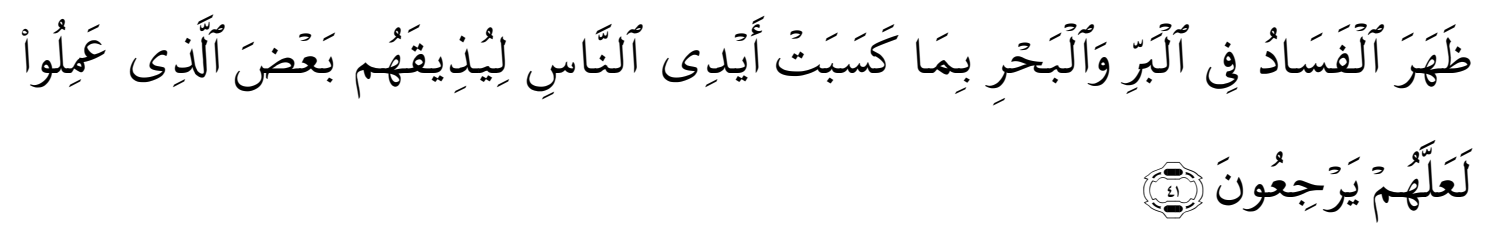

Terjemahannya:

Telah nampak kerusakan di darat dan di laut disebabkan karena perbuatan tangan manusia, supaya Allah merasakan kepada mereka sebahagian dari (akibat) perbuatan mereka, agar mereka kembali (ke jalan yang benar). ${ }^{6}$

Secara ekplisit ia menyebutkan:

Ilmu ciptaan manusia hanya menghasilkan mala petaka yang manghancurkan kehidupan manusia sendiri, segala benda dan materi yang diperolehnya sendiri membawa mereka tenggelam dan hancur bersama-sama dalam kehidupan yang tidak berujung dan tak berpangkal.

Peradaban yang dibina menurut ilmu pengetahuan, menurut filsafat yang dijadikan landasan hidupnya, seluruhnya hancur berantakan, menjadikan mereka hewan, binatang yang biadap. ${ }^{7}$

Baginya kehidupan yang berlandaskan kepada isme-isme dan pikiran manusia hanya akan menghantarkan manusia itu sendiri kepada perlakuan dan aktivitas kehidupan layaknya kehidupan binatang yang tidak beradap. QS. Al-A'rāf/7: 179

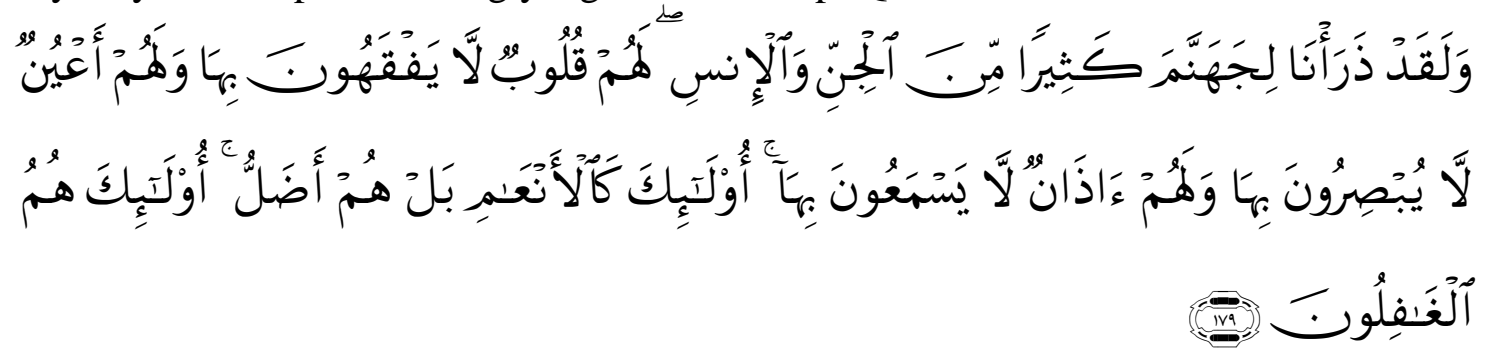

Terjemahannya:

Dan Sesungguhnya Kami jadikan untuk (isi neraka Jahannam) kebanyakan dari jin dan manusia, mereka mempunyai hati, tetapi tidak dipergunakannya untuk memahami (ayat-ayat Allah) dan mereka mempunyai mata (tetapi) tidak dipergunakannya untuk melihat (tanda-tanda kekuasaan Allah), dan mereka mempunyai telinga (tetapi) tidak dipergunakannya untuk mendengar (ayat-ayat

individualis akan melanjutkan percapaian dan kehendak pribadi. Mereka menentang intervensi dari masyarakat, negara dan setiap badan atau kelompok atas pilihan pribadi mereka.

${ }^{6}$ Kolektivisme adalah "ajarån atau faham yang tidak menghendaki adanya hak milik perseorangan, baik atas modal, tanah, maupun alat-alat produksi (semua harus dijadikan milik bersama, kecuali barangkonsumsi. Lihat: Anton M Moeliono dkk., Kamus Besar Bahasa Indonesia, (Jakarta: Depdikbud Balai Pustaka, 1990), h. 111.

${ }^{6}$ Kementerian Agama RI, Al-Quràn dan Terjemahnya, h. 408

${ }^{7}$ Fathul Muin Dg Maggading, ${ }^{9}$ Gerak Langkah Muhammadijah Terlibat dalam Kekaburan, h.7 
Allah). Mereka itu sebagai binatang ternak, bahkan mereka lebih sesat lagi. Mereka Itulah orang-orang yang lalai. ${ }^{7}$

Menurutnya inilah way of life al-magḍūb a'laihim yang harus ditinggalkan oleh orang-orang beriman dalam segala bentuk manifestasinya.

\section{PENUTUP}

Berdasarkan hasil penelitian di atas menunjukkan bahwa KH Fathul Muin Dg Maggading mendefenisikan kata tajdīd sebagai pemurnian, banyak hal yang mendorongnya untuk melakukan pemurnian, diantaranya masalah pudarnya pemahaman ummat Islam akan fungsi utama dari al-Quran dan al-Sunnah. Selain itu, kondisi sosial seperti kondisi ummat Islam yang dalam masa transisi atau peralihan kebudayaan, dimana ilmu-ilmu Barat sudah menjadi penentu ukuran kebenaran dalam kehidupan, demikian juga dengan politik, dimana Masyumi dibubarkan dan para pemimpin revolusioner disudutkan. Menurutnya hanya ada satu jalan untuk merealisasikan pemurnian ini yaitu kembali kepada al-Quran dan al-Sunnah. Ia membagi pemurnian kedalam tiga bagian yaitu pemurnian dalam bidang aqidah yaitu menjadikan al- Quran dan al-Sunnah sebagai satu-satunya landasan dalam kehidupan, ibadah yaitu tunduk dan patuh terhadap peraturan-peraturan yang telah disyariatkan dan muamalah yaitu menjadikan Islam sebagai jalan hidup (Way of Life) dimana ketiga bentuk pemurnian ini terinspirasi dari surah al-Fatihah.

${ }^{7}$ Kementerian Agama RI, Al-Quran dan Terjemahnya, h. 173 


\section{DAFTAR PUSTAKA}

Abi al Husain Ahmad bin Fāris bin Zakaria, Mu'jam Maqaȳ̄s Al-Lugah, Cet. I; Bairut: Dār Uhyā al-Turās̀ Al Arabi, 2001.

Abu Dāud Sulaimān bin Al Asya’s Al Sijastānī, Sunan Abì Dāud, Juz 5, Bairūt: Dār Al Kitāb Al Arābī, 2009.

Ahmad, Abd.Kadir, Ulama Bugis, Makassar: Indobis Publishing, 2008.

Aldjufri, Moh. Salim, Wahdah Islamiyah di Gorontalo (Studi Tentang Corak Pemikiran dan Respon Masyarakat), Jakarta: Kemetrian Agama RI, 2011.

Aqsha, Darul, K.H. Mas Mansur (1896-1946): Perjuangan dan Pemikiran, Jakarta: Erlangga, 2005.

Atsarī, Abdullah bin Abdul Hamīd, Al-Wā̄z fi Aqīdah al-Salaf al-Shālih, (Ahli alSunnah wa al-Jamā'ah), Cet. I; Riyadh, Dār al-Rāya li Nasyr wa al Tauzī', 1418 H.

Bagus, Lorens, Kamus Filsafat, Jakarta: Gramedia, 1996.

Bashari, Agus Hasan, Mewaspadai Gerakan Kontekstualisasi al-Quran, Surabaya: Pustaka as-Sunnah, 2003.

Bosra, Mustari dkk, Menepak Jejak Menata Langkah Sejarah Gerakan dan Biografi Ketua-Ketua Muhammadiyah Sulawesi Selatan, (Cet. I; Yogyakarta: Suara Muhammadiyah, 2015.

Depertemen Pendidikan Nasional, Kamus Besar Bahasa Indonesia, Jakarta: Pusat Bahasa, 2008.

Dg Maggading, Fathul Muin, Diktat Peladjaran Keimanan 1, t.cet, t.p, 1970.

, Diktat Peladjaran Keimanan II

, Diktat Peladjaran Tafsir al-Quran 1

, Gerak Langkah Muhammadijah Terlibat dalam Kekaburan.

Hamid, Ilham, dkk, Matahari Pembaharuan di Serambi Madinah Menelusuri Tapak Sejarah Muhammadiayah Kota Makassar, Makassar: Majelis Pustaka PDM Kota Makassar dan LSQ Makassar, 2015.

Ibn Manzur, Al Imām Al Allāmah Abu Al Fadl Jamāl Al Dīn Muhammad bin Mukrim bin Maẓur Al Ifriqī Al Misrī, Lisān Al Arab, Juz 2, Bairūt: Dār Sādir, t. tahun.

Kadir, Ilham, http://ilhamkadirmenulis.blogspot.co.id/2013/04/syariat-islam-di-sulselsebuah,pranata.(17Oktober 2016).

Kementerian Agama RI, Al-Qura'n dan Terjemahannya, Cet. I; Jakarta: al-Hadi Media Kreasi, 2015.

Maqrī, Al Ālim Al Allāmah Ahmad bin Muhammad bin Ali Al Faiwamī Al-, Misbāh Al Mun Al Munīr, Bairūt: Maktabah Libanon, 1987. 
Maraghi, Abdullah Mustafa al-, Pakar-Pakar Fiqih Sepanjang Sejarah, Yogyakarta, LKPSM, 2001.

Matullada, A., Sejarah Masyarakat dan Kebudayaan Sulawesi Selatan, Makassar: Hasanuddin University Press, 1998.

Maudūdī, Abu Al A'lā' al-, Mūjaz Tānīkh Tajdíd al-Dīn wa Ihyāuhu wa Waqi' Al Muslimina wa Sabīl Al Nuhūd Bihim, (Cet. II; Libanon: Dār Al Fikr Al Hadīś, $1386 \mathrm{H} / 1967 \mathrm{M}$.

Moeliono, Anton M dkk., Kamus Besar Bahasa Indonesia, Jakarta: Depdikbud Balai Pustaka, 1990.

Munāwī, Muhammad Abdul Raūf al-, Faid Al Qadìr Syarh Al Jāmi' Al Soghīr, Juz 1, Cet. II; Bairūt: Dār Al Ma’rifa, 1391 H/1972 M.

Noer, Delier, Gerakan Modern Islam di Indonesia, Jakarta: LP3S, 1996.

Pasha, Mustafa Kamal, Ahmad Adaby Darban, Muhammadiyah sebagai Gerakan Islam Dalam Perspektif Hostoris dan Ideologis, Cet. I; Yogyakarta: Lembaga Pengkajian dan Pengalaman Islam (LPPI), 2000.

Rizal, Hannabil, dkk., Profil Raja dan Pejuang Sulawesi Selatan, (Makassar: YAPMI, 2004.

Saīd, Busțāmī Muhammad, Mafhūm Tajốd Al Dīin, Cet. III; Jeddah: Markaz Al Ta’ṣīl li Al Dirāsāt wa Al Buhūś, 1436H/2010M.

Suhartono, Suparlan, Filsafat Pendidikan, Jogjakarta: Ar-Ruzz Media, 2007.

Supriadi, Dedi, Perbandingan Mazhab dengan Pendekatan Baru, Bandung: CV Pustaka Setia, 2008.

Thosibo, Anwar, Historiografi Perbudakan Sejarah Perbudakan di Sulawesi Selatan Abad XIX, Magelang: Indonesia TeraI, 2001), h. 26.

Tim Penyusun, Kamus Besar Bahasa Indonesia, Jakarta: Balai Pustaka, 1989.

Zahabī, Al- Imām Syamsuddīn Muhammad bin Ahmad bin Uṡmān al-, Siyar al-A'lām al-Nubalā ', Juz 2, Cet. XII; Bairūt: Muassasah al-Risālah, 2001.

\section{Sumber Internet}

Majelis Tarjih dan Tajdid Pimpinan Pusta Muhammadiyah, Sejarah, http://tarjih.muhammadiyah.or.id. 12 Oktober 2016.

http://www.uin-alauddin.ac.id/uin-124-.html, (17 Oktober 016).

Karl Marx dan Friedrich Engels, https://id.wikipedia.org/wiki/Komunisme, (1 Januari 2016. 